\title{
The communist world from dawn till dusk. A political geography perspective
}

\begin{abstract}
The article presents the territorial evolution of the communist world from its beginning up until the present day. It argues that the communist world was created in 1917 and that it has survived the end of the Cold War It shows various ways of understanding its nature in the past as well as in present times and shows the variability and ambiguity of the communist world, including its territorial dimension, thereby encouraging reflection and discussion.

Keywords

Communism • socialism • world system • evolution • territorial shape

(C) University of Warsaw - Faculty of Geography and Regional Studies
\end{abstract}

Marcin Wojciech Solarz

Institute of Regional and Global Studies, Faculty of Geography and Regional Studies, University of Warsaw,

e-mail: mwsolarz@uw.edu.pl

Received: 4 April 2012 Accepted: 11 June 2012
Communist world: its birth and original shape

During the 18th and 19th centuries, industrialisation started the division of the world into the rich North and poor South that we see today, but it also resulted in the communist world coming into existence (Solarz 2009). In theory, determining the date of birth of communism as a world system should not be difficult, yet in practice it is not easy. The communist world did not simply come to existence at the end of the Second World War (Kuźniar 1995), but its creation started as early as November 1917 in Russia and ended de facto not later than at the very beginning of the 1920s with the end of the civil war in Russia and the stabilisation of the Bolshevik government. So the idea of a pre-war origin of the world socialist system is supported by at least several important reasons:

- From the very beginning, the system was present in more than one country and by 1920 it was forming not only in the territory of the previous Tsars' empire (from the very beginning, Russia was a political and territorial core of the communist system) but also beyond (e.g. in Germany, Hungary). Soviet Russia absorbed at least several countries and societies which were trying to gain permanent independence (e.g. Belarus, Ukraine, Transcaucasian republics, the Alash Orda, the Basmachi's territories) and made satellite states out of two other countries - Mongolia and the Tuvan People's Republic (Republic of Tannu-Tuva) (Fig.1);

- In 1917 the Bolsheviks' aim was to gain power not only in Russia. They treated the Russian Revolution as the beginning and an impulse for world revolution;
- The idea of the Soviet Union being presented as a new segment of the world was supported also by the façade of the Soviet political regime as a union of equal republics which was created from the very beginning;

- Making the "world" label dependent on the number of communist states may be seen as a misunderstanding, also because Marxist theory assumed that in the distant future, when the proletarian state suppresses the exploiters' resistance, it will die out and any political power will be destroyed (Kołakowski ca 2000);

- Before the Revolution changed the face of the Russian state from white to red, Russia had already been interpreted as a "world", even if this perspective was limited only to Europe and Asia (Zdziechowski 1993);

- Last but not least, from its beginning Red Russia appeared as, was shown as and was believed to be a new phenomenon in the international arena in terms of quality (Davies 1998).

So from the very beginning of "red" Russia one could view it as a completely new global structure: a new world which, although enslaved, centralised, and generally speaking a part of one state organism and still territorially limited (Fig. 1), was at the same time strongly expansive, not accepting any borders as permanent (even the very name the "Union of Soviet Socialist Republics" which was assumed in 1922 does not have any geographical reference). From the very beginning, communism was a global project. It was designed to be the world system and what is equally 


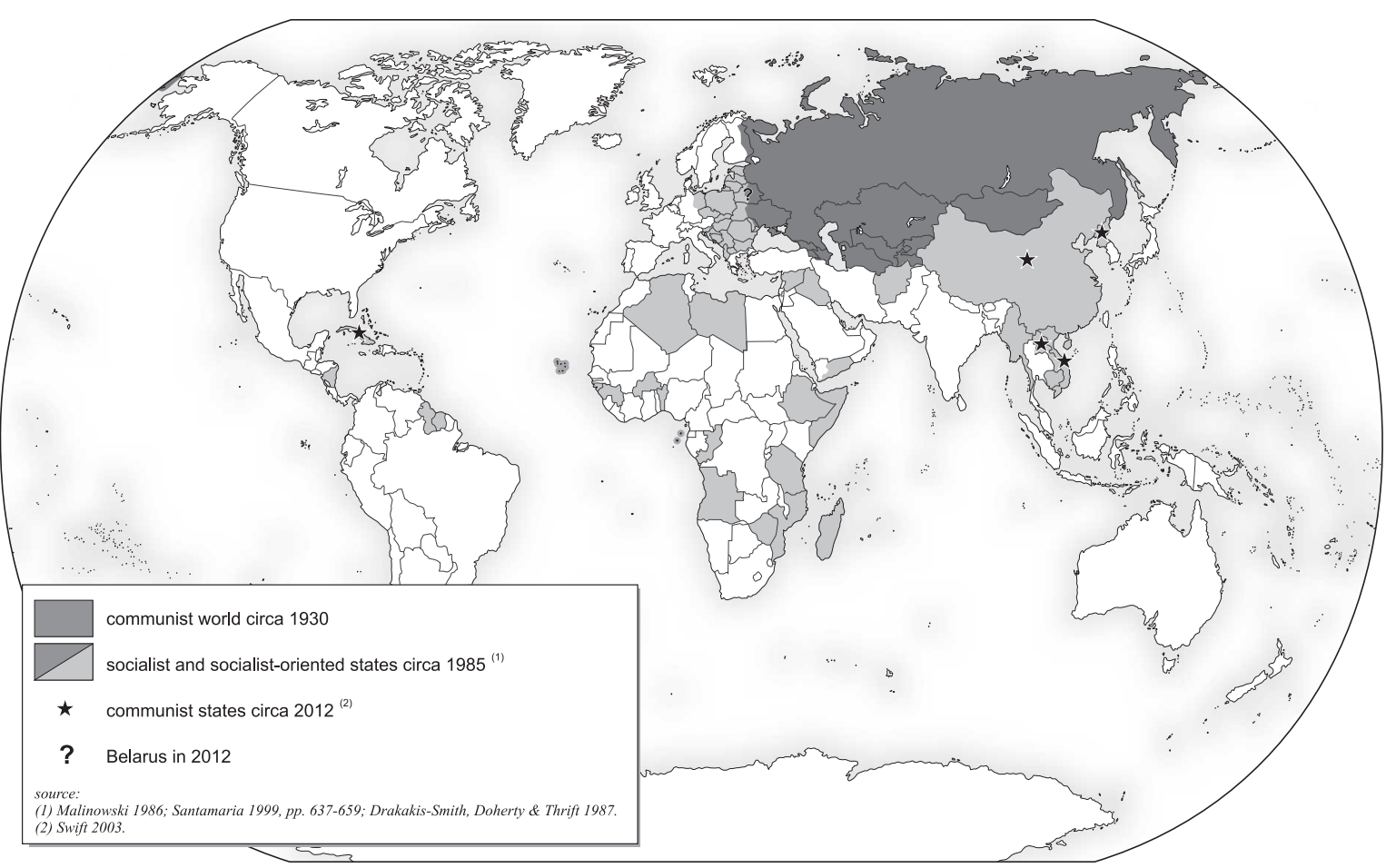

Fig 1. The communist world circa 1930, 1985 and 2012

important, an alternative for the world of that time. So in fact, the number of geopolitical units into which the communist world was divided, as well as their international legal status, were of lesser importance. All in all from its beginning, "red" Russia could be seen as a "new world's world".

The defeat in 1920 by Poland and the post-war economic and political stabilization of the capitalist world only temporarily (until 1939) stopped further Soviet expansion, leading to Stalinist 'socialism in one country'. However the rivalry between Stalin and Trotsky and Stalin's eventual victory may be crucial for the understanding and delimitating of the socialist world, especially after 1945. Stalin's victory meant the Russification of the Soviet Union or the Sovietisation of the world revolution (Davies 1998; Kołakowski ca 2000; Wiatr 1999). While initially the communist world was considered to be the world ruled by the Communists, since then one can argue that it was the world subordinated to Soviet foreign politics.

\section{Globalisation of socialist system during the Cold War}

The result of the first great battle (1914-1918) in the European thirty-year war (1914-1945) was the transformation of "white" Russia into "red" Russia. The second great battle (1939-1945), which finally ended the great power status of European states and led to interbloc rivalry, made the globalisation of communist world possible. The Molotov-Ribbentrop Pact of 1939 and the Soviet occupation of the Central and Eastern Europe as a result of the Second World War strengthened the interpretation of the group of communist states as a "world" even though it was still deprived of a global character. All in all its global character was an easy measurable cost and visible effect of the Cold War, since one of the main char- acteristics of the Cold War was a permanent territorial expansion, a horizontal escalation, from Europe to the rest of the world (Kennedy 1995). The globalisation of the socialist system during the Cold War was inevitable for a number of reasons:

- It was dictated by the very logic of Cold War rivalry between superpowers. An important element of the rivalry was that the Soviet Union and the West made allies all over the world and competed for new partners or at least to prevent Third World countries from joining the opposing camp (Kennedy 1995);

- At the same time, after 1945 one can observe the biggest wave of decolonization in history. In general, the lack of development and the colonial past (most of the former colonial metropolises remained in alliance with the USA) meant that the Third World was oriented towards the left of the political spectrum. Further, most of the newly independent states were also politically and economically weak, open to foreign help and influences;

- Expansiveness is a significant characteristic of totalitarian states (Wojtaszczyk 2003, p 269) to which the Soviet Union undoubtedly belonged;

- During the Second World War the USSR was still interested in non-European regions (the Middle and Far East), although it concentrated almost entirely on fighting with Germany (Kennedy 1995);

- Rules which were a bone of contention between the West and East were universal in nature (Kennedy 1995);

- Post-war political chaos encouraged the superpowers to expand (Kennedy 1995);

- During the Second World War, the Allies supported numerous and various resistance forces which after 1945, frequently began competing with each other for power while retaining their communist or anti-communist affiliations (Kennedy 1995). 


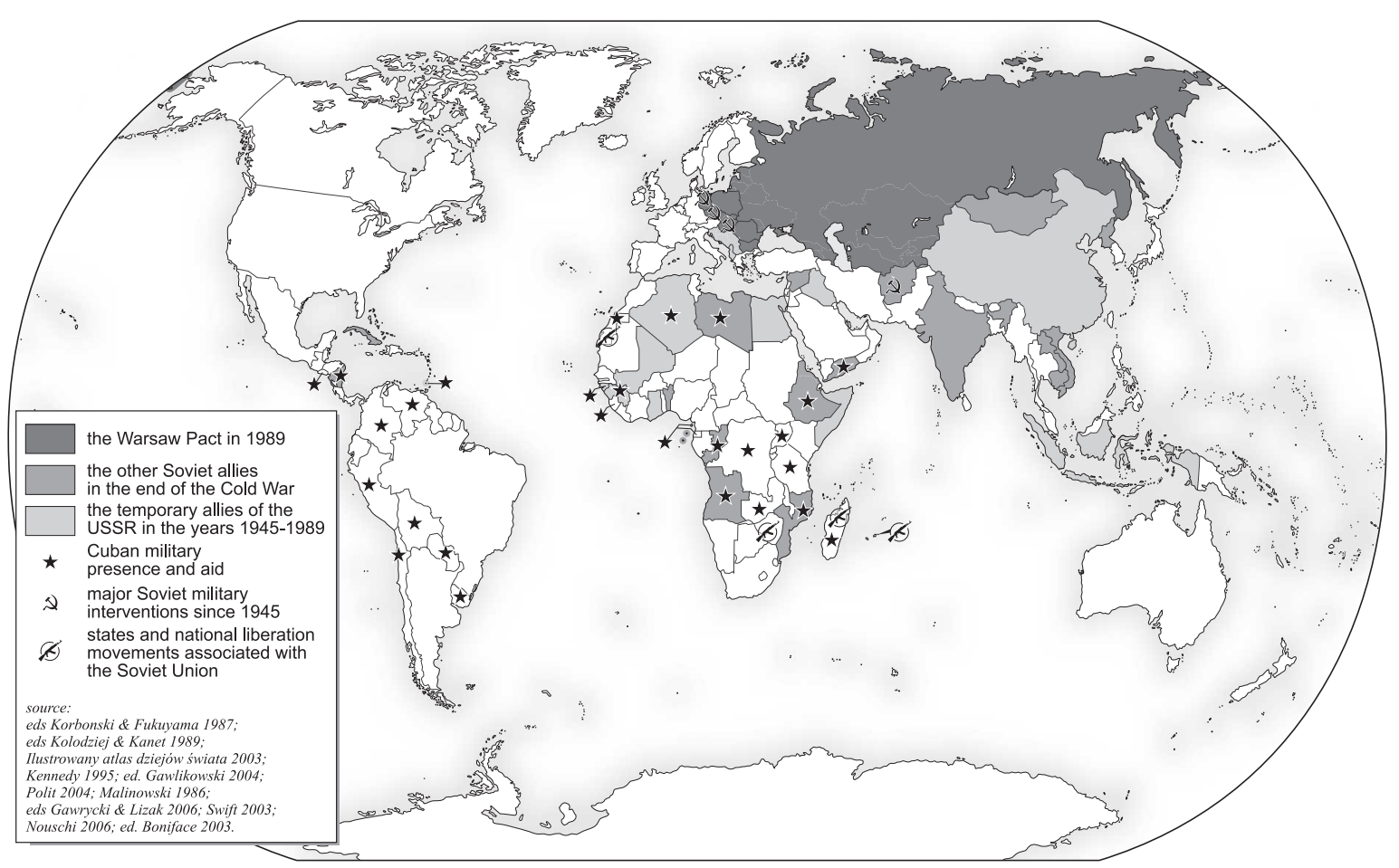

Fig 2. The Soviet Union and its allies during the Cold War - the communist world from the realist perspective

At the beginning of the Cold War, the United States was a more active party in the global arena, for it had military bases beyond the Western hemisphere and many countries were interested in receiving American economic and military support (Kennedy 1995). By the end of the 1950s (before 1960) most of the UN members of the time were allied (at least formally) with the USA. In first years of the Cold War, Washington's advantage over Moscow seemed to be even greater if we take into account the fact that America's allies - Great Britain, France, Portugal, Belgium and The Netherlands - still had power over vast areas of their colonies. At that time, the Soviet Union's operations were characterised by a much smaller scope which was the consequence of inter alia, its limited military and technical capabilities. The postwar Stalinist USSR interest in Third World regions was limited mainly to Asia, particularly to countries situated along southern borders of the Soviet empire (Kennedy 1995; Kanet 1989, pp 36, 4042). USSR policy towards the Third World changed only after Stalin's death, when Khrushchev seized power and opened the Soviet Union to the global South (Kanet 1989, p 36; Kennedy 1995). The first signs of changes in Soviet strategy were three subsequent events of 1955: Soviet approval of the Bandung Conference (April), the Czechoslovak-Egyptian agreement on the supply of weapons (July) and Khrushchev's broadly-publicised trip to Afghanistan, Burma and India (August) (Fukuyama 1987, p 26). Obviously the USSR faced a number of barriers on entering the Third World, yet the post-war dynamics of international relations and the internal political life of the newly independent states of the South, as well as their social and economic situation, created favourable conditions for USSR expansion. Finally, when the USSR overcame some difficulties, e.g. military and transport, there was a significant increase in its presence and importance in the Third World (Kennedy 1995; Kanet 1989, pp 40-49, 52, 55-56; Malinowski 1986; Kuźniar 2005).

So in this way, a natural territorial Cold War expansion led to a growing number of states being connected directly or indirectly with the Eastern Bloc and meant that the communist world became global - socialist countries appeared almost in each continent. However, until the communist world ended no one, either in the socialist East or in the capitalist West, was able to say to what extent the communist East had spread into the global South. Objectively speaking, even the very manner of defining it was a problem - does one define it according to ideologicallegal (political-economic) or political-strategic (political-military) criteria? Or even possibly objective or completely discretionary criteria? It may be easily assumed that during the Cold War, the nature and borders of the communist world were better explained by formal and informal allied relationships with the Soviet Union (Fig. 2) than the unclear ideological-legal hints of a political and economic nature (Fig. 1). However, the political-strategic perspective means that one should include in the communist world countries that were non-communist but were nevertheless allied with the USSR. These countries worked to its advantage in terms of global balance and de facto contributed to its potential future victory in the Cold War. However, while application of politicalmilitary characteristics to define the Cold War communist world seems to characterise its nature most precisely, even this criterion does not enable us to set precise, undisputed borders for the world socialist system, especially in the global South.

The above-mentioned ways of defining the post-war communist world also lead to the adoption of one of two different internal 
structures related to either ideological or strategic characteristics. In the first case the Soviet Union is a dominant center holding its satellites, but with some weaker independent ideological poles, e.g. China and Yugoslavia (after break with the USSR). In the second case, the Soviet Union is the core of the communist international system while all other countries are its satellites but with different degrees of dependence. It is worth noting that the latter construction corresponds to the victorious Stalin's view on the relationship between the USSR and the world revolution.

\section{Post-cold war communist world}

The trichotomic division of the globe into capitalist First World, communist Second World and underdeveloped Third World is undoubtedly one of the most characteristic features of the 20th century. One may argue convincingly that the 20th century began only when the tripartite division of the world materialised (1917-1920) (Solarz 2012) and ended when the division started to devalue, no later than 1991, with the final defeat and collapse of the USSR. It was also then that the world system of socialist states practically left the public discourse about the world and become widely understood as only a historical category. Generally, one used to notice only individual communist countries that were more or less isolated and anachronistic political enclaves that remained after the Cold war period and they were not usually perceived as part of a larger, individual entirety, system or world. This was obviously supported by the collapse and disintegration of the USSR.

However the fall of the Soviet Union did not actually make the global trichotomy totally outdated and invalid, as after 1991 socialist states still existed. Rather it drastically devalued this cognitive and analytical perspective in any discourse about world structure, since one of the two polar opposites of the world order which was, at the same time, the managing centre and heart of the communist world had disappeared. For this reason there was a quite widespread rejection of tripartite structure of the world. Yet it seems that, as at the beginning of 1920s, an extraordinary territorial reach or the existence of a large number of communist states was not necessary criterion to distinguish the socialist world, the territorial and quantitative decline of socialist states after 1988 was not enough to announce its collapse, especially when taking into account the fact that socialist states still occupy quite a large part of the globe. Even today they are present on two continents at least and above all, they still have great population potential. The decrease in the number of socialist states at the turn of the 1980s and the 1990s was a result of the defeat and collapse of the USSR. One may suppose however that if the USSR had not collapsed, even significant changes in the borders of the communist world would not have excluded this category from the global discourse. Therefore, the turn of the 1980s and the 1990s did not mean that the tripartite world view was invalidated. Rather, it meant that the collapse of the (up until then) very powerful and influential communist challenge to the world order that had arisen thanks to the industrial revolution (which also gave rise to the communist system), as well as the subsequent effects this had on world public opinion, led to the regaining of the unquestioned primacy of the global dichotomy 'developed - underdeveloped countries' in the description of world structure.

Thus, one may try to create a map of existing communist countries. One such attempt was made by John Swift (2003) who distinguished the contemporary 'surviving communist world' as being limited to five countries in 2002: the People's Republic of China, Laos, North Korea, Cuba and Vietnam (Fig. 1). Such delimitation of the boundaries of the contemporary communist system does not generally raise serious objections and remains valid, although the cases of modern Belarus (according to Lukashenko: "market socialism") and perhaps also of Venezuela (according to Chavez: "socialism of the 21st century") are worth discussing seriously. Limiting the communist system to a handful of countries does not mean, however, that its post-Cold War remnants have been marginalized and do not matter in the modern world. One cannot imagine the present world without the "Made in China" label for example. Today, China is an important partner and competitor for all great powers and it is worth noting that at present, as many as $1.348 \mathrm{bn}$ out of a total population of $7 \mathrm{bn}$ are "red" Chinese people. Moreover, taking the great territorial collapse of the socialist system at the turn of 1980s and 1990s into account, one should note that $21 \%$ of the world's population still lives in communist countries whereas in 1980, when the USSR seemed to be at the height of its power, the population of socialist countries was "only" $32.6 \%$ of total world population (Barbag 1985, p 698). Apart from China, North Korea (mainly as a regional or even global problem) and Cuba (as an unlimited source of political inspiration for the left-leaning leaders of some countries in Latin America) are clearly visible in the international arena.

Therefore, communism is not yet a idea that has been consigned to history. Marxism is still an important and influential intellectual trend. The existence of communist ideology in the modern world may be also demonstrated by the "New Europe Barometer" research conducted in 2005 by the Hungarian TARKI Social Research Institute in eleven countries that, until the 1980s and the 1990 s were a part of world communist system. Their surveys showed that in these countries, over $10 \%$ of the population supported the idea that socialism is superior to democracy (Czech Republic $-13 \%$ of the population, Belarus - $14 \%$, Poland $-17 \%$, Estonia - 18\%, Slovenia - 22\%, Ukraine and Hungary - 23\%, Romania - 24\%, Slovakia - 31\%, Russia - 36\%, Bulgaria - 38\%). Taking the total population of eleven countries into account, the people who supported the idea amounted to nearly one quarter of the population (24\%). What is more, in each of the above-mentioned countries, at least one fifth of citizens were not concerned whether their government was democratic or socialist (Czech Republic -18 , Slovakia and Romania - $21 \%$, Bulgaria - $30 \%$, Russia - 35\%, Estonia - 37\%, Hungary - 38\%, Poland - 42\%, Ukraine - $43 \%$, Slovenia - $48 \%$, Belarus - $52 \%$ ). Summing up, for as much as one third of the total population in the countries in which the research was conducted, the choice between democracy and communism did not exist because the type of political system in their country was not of relevance to them. At the same time, in Russia, Bulgaria and Slovakia there were more supporters of so- 
cialism than of democracy while the Czech Republic was the only country where the opinion that democratic government is better than socialist government won more than half of votes ('Nostalgia za komunizmem' 2006; 'Nie mija tęsknota za socjalizmem' 2006). In Central and Eastern Europe, with the possible exclusion of Belarus, the idea of socialism as a political system is dead yet it still lives on in people's minds, which is relevant as most of these countries observe democratic rule. Thus Vicky Randall and Robin Theobald's comment that although at the end of 1980s most communist countries rejected the system, there are still some reasons to distinguish a group of ex-socialist countries because the old system will probably long affect their development, is correct (Randall \& Theobald 1998). According to Ryszard Kapuściński this system leaves behind permanent marks in people's mentality, their perception of the world and judgement of reality (Kapuściński 2007). Since it is believed that globalisation combines elements of the rich North and the poor South and because it is people not places that are "carriers" of development levels, maybe even the communist world also remains as a decentralized global social space? For these reasons, we believe that communism as an element of international reality and even as its active organizer did not leave the arena of history at the turn of 1980s and 1990s when the Cold War ended. Certainly, at present the communist world does not have a managing core like the one that the Soviet Union represented during the Cold War, but the global South (and at least periodically the global North too) was always multipolar and decentralized and it was always one of the "world's worlds". It is also possible that the above list of post-Cold war communist countries is too short. Maybe in order to show the real borders of the group of modern communist countries, one should also include not only the countries which officially support communist ideology but also those countries which, despite rejecting a socialist facade, continue with the previous period in some way, whether personally or legally. This can be in terms of philosophy and mechanisms of exercising power or leaders' habits. Their political systems are still closely controlled, basic political rights and civil liberties are not observed, power is held or controlled by previous elites or the "second rank" people or interest groups that were important pillars of the old system, its beneficiaries and followers such as the army, structures that originate from ex-secret police, lower levels of administrative and party apparatus. This new attitude towards the delimitation of contemporary communist world borders may seem even more justified, for at least during the final stages of the Cold War, for many communist decisionmakers ideology was only a useful, yet empty ritual - a cynical excuse for holding power, benefiting from it and controlling political, social and economic life. Also from such a perspective, the modern communist world is still quite an extensive system with branches in several continents. Maybe it would make sense to place within its borders countries such as modern Russia or the post-Soviet states in Central Asia? Such a definition cannot be rejected a priori. Analogous to the global North and global South, for being a product of modernity, the world socialist system was characterised by the fact that both the criteria distinguishing it and its borders were changing over time. So it is possible that after 1989 one can simply observe another change. By seeking the contemporary communist world's borders, whether according to political-legal or political-personal criteria, we may not only see its existence but also its vast scale. Both perspectives are interesting and at the same time, both seem to be true.

\section{References}

Barbag, J 1985, 'Mapa polityczna świata', in Geografia świata, ed J Barbag, Wydawnictwa Szkolne i Pedagogiczne, Warszawa, pp. 695-700. (In Polish)

Boniface, P (ed.) 2003, Atlas des relations internationales, Hatier, Paris. Davies, N 1998, Europa. Rozprawa historyka z historią, Wydawnictwo Znak, Kraków. (In Polish)

Drakakis-Smith D, Doherty J \& Thrift N 1987, 'Socialist development in the Third World. Introduction: What is a socialist developing country?', Geography, vol. 72, no. 4, pp. 333-335.

Fukuyama, F 1987, 'Soviet Strategy in the Third World' in The Soviet Union and the Third World, eds A Korbonski \& F Fukuyama, Cornell University Press, Ithaca, London, pp. 24-45.

Gawlikowski, K (ed.) 2004, Azja Wschodnia na przełomie XX i XXI wieku. Przemiany polityczne $i$ społeczne, Wydawnictwo TRIO, Warszawa. (In Polish)

Gawrycki, MF \& Lizak W (eds) 2006, Kuba i Afryka. Sojusz dla rewolucji, Oficyna Wydawnicza ASPRA-JR, Warszawa. (In Polish)

Ilustrowany atlas dziejów świata 2003, Wydawnictwo G+J, Warszawa. (In Polish)

Kanet, RE 1989, 'The Evolution of Soviet Policy Towards the Developing World From Stalin to Brezhnev' in The Limits of Soviet Power in the Developing World, eds EA Kolodziej \& RE Kanet, The Johns Hopkins
University Press, Baltimore, pp. 36-61.

Kapuściński, R 2007, Rwący nurt historii. Zapiski o XX i XXI wieku, Wydawnictwo Znak, Kraków. (In Polish)

Kennedy, P 1995, Mocarstwa świata. Narodziny, rozkwit, upadek, Książka i Wiedza, Warszawa. (In Polish)

Kolodziej, EA \& Kanet RE (eds) 1989, The Limits of Soviet Power in the Developing World, The Johns Hopkins University Press, Baltimore.

Kołakowski, L ca 2000, Główne nurty marksizmu. Część II. Rozwój, Zysk

i S-ka Wydawnictwo s. c., Poznań. (In Polish)

Korbonski, A \& Fukuyama F (eds) 1987, The Soviet Union and the Third World, Cornell University Press, Ithaca, London.

Kuźniar, R 2005, Polityka i siła. Studia strategiczne - zarys problematyki, Wydawnictwo Naukowe SCHOLAR,Warszawa. (In Polish)

Malinowski, MJ 1986, Ideologie afrykańskie 1945-1985, Zakład Narodowy im. Ossolińskich, Wrocław. (In Polish)

'Nie mija tęsknota za socjalizmem' 2006, Gazeta Wyborcza, 8 March. Available from: <http://wiadomosci.gazeta.pl>. [12 March 2006] (In Polish)

'Nostalgia za komunizmem' 2006, Rzeczpospolita, 9 March, p. 2. Available from: <http://archiwum.rp.pl>. [12 March 2006] (In Polish) Nouschi, M 2006, Mały atlas XX wieku. Historia, Dom Wydawniczy Bellona, Warszawa. (In Polish) 
Polit, J 2004, Chiny, Wydawnictwo TRIO, Warszawa. (In Polish) Randall, V \& Theobald, R 1998, Political Change and Underdevelopment. A critical Introduction to Third World Politics, Macmillan Press Ltd, Houndmills, Basingstoke.

Santamaria, Y 1999, 'Afrokomunizmy: Etiopia, Angola, Mozambik' in Czarna księga komunizmu. Zbrodnie, terror, prześladowania, eds S Courtois, N Werth, J-L Panné, A Paczkowski, K Bartosek \& J-L Margolin, Prószyński i S-ka, Warszawa, pp. 637-659. (In Polish)

Solarz, MW 2009, Północ-Południe. Krytyczna analiza podziału świata na kraje wysoko i słabo rozwinięte, Wydawnictwa Uniwersytetu Warszawskiego, Warszawa. (In Polish)

Solarz, MW 2012, 'North-South, commemorating the first Brandt Report: searching for the contemporary spatial picture of the global rift', Third World Quarterly, vol. 33, no. 3, pp. 559-569.

Swift, J 2003, The Palgrave Concise Historical Atlas of the Cold War, Palgrave Macmillan, Houndmills, Basingstoke \& New York.

Wiatr, JJ 1999, Socjologia wielkiej przemiany, Krajowa Agencja Promocyjna, Warszawa. (In Polish)

Wojtaszczyk, KA 2003, 'Państwo współczesne' in Społeczeństwo i polityka. Podstawy nauk politycznych, eds KA Wojtaszczyk \& W Jakubowski, Oficyna Wydawnicza ASPRA-JR, Warszawa, pp. 233-284. (In Polish)

Zdziechowski, M 1993, Wybór pism, Wydawnictwo Znak, Kraków. (In Polish) 